\title{
Nutritional and sensory analysis of millet based sponge cake
}

\author{
Kwaw Emmanuel; Sackey, Augustina Sackle \\ Department of Hotel, Catering and Institutional Management, Cape Coast Polytechnic, Cape Coast, Ghana
}

Email address:

nyangoahkwaw@yahoo.co.uk (Kwaw, E), sacklesackey@yahoo.com (Sackey, A. S.)

\section{To cite this article:}

Kwaw Emmanuel; Sackey, Augustina Sackle. Nutritional and Sensory Analysis of Millet Based Sponge Cake. International Journal of Nutrition and Food Sciences. Vol. 2, No. 6, 2013, pp. 287-293. doi: 10.11648/j.ijnfs.20130206.14

\begin{abstract}
Food companies are faced with an increased demand by health professionals and consumers for healthier food products. The need for flours that are free of gluten (such as millet, tapioca, potato, soy, flax, etc.) are becoming progressively more popular and are offering new sales potentials for food companies. It is against this background that the study was undertaken to produce millet based sponge cakes with the view of improving the sensory and nutritional values of the product. In addition to a control sample using only wheat flour, ten different cake formulations were prepared using varying wheat and millet flours ratios. Sensory analysis using forty untrained panel and proximate analyses were performed. The results revealed that significant differences in visual puffiness, appearance, texture/mouthfeel, moistness and smell acceptability were not observed among these products. Superimposition of the optimal areas having a score greater than 6.0 from each attribute was done to obtain an optimal formulation range. However, the sensory assessments of the products on the 9-point hedonic scale depicted that all products scores were more than 6 on the scale which is an indication that all sensory attributes were at least liked slightly in each case by the panel. Panel was able to correctly discriminate between the different samples in terms of the sensory attributes on the 9-point hedonic scale. However, the overall liking of the samples as perceived by the panel indicated that all products were acceptable with Sample E being the most preferred. Positive purchase intent was noticed among the panel hence offering new sales potential for the millet based cakes. There was improvement on the nutritional content (carbohydrate, fat and ash) of the formulations as the proximate analysis generally showed a mean increase of $2.08 \pm 0.36 \%$ for ash and $33.41 \pm 3.32 \%$ for fat against the control sample of $1.53 \%$ and $30.96 \%$ respectively. No significant change was observed in the protein content $(7.43 \pm 0.92 \%$ against $7.44 \%)$. However, there was a decrease $(71.41 \pm 5.38 \%)$ in carbohydrate content against control sample of $77.43 \%$.
\end{abstract}

Keywords: Millet Sponge Cake, Sensory Attributes, Nutritional Values, Overall Acceptability, 9-Point Hedonic Scale

\section{Introduction}

In recent years, there has been an increased demand by health professionals and consumers for healthier food products. However, food companies have met this challenge with relatively limited success because consumers often view healthy food choices to be in direct conflict with enjoyable eating [1]. However, some food formulations have been developed to produce healthy foods such as gluten free bread, probiotic yoghurts etc. This study seeks to produce millet based sponge cake.

Millet is gluten free and has been found to be a healthy food choice for people with celiac disease (the most common disease caused by cereal protein ingestion). Millet is a highly variable small seed grass, widely grown around the world as cereals or grain for food. It grows well on poorly fertilized and dry soils, particularly in regions with hot climates and short rainfall periods. It has a short growing season and its capability of producing good yields of grain under conditions unfavourable to most other cereals [2]. The most widely grown variety is the pearl millet, which is an important crop in Asia and Africa.

Millet, like other cereals contain about seventy -five percent $(75 \%)$ complex carbohydrate and ten percent $(10 \%)$ in addition to fat and fibre (roughage). The high valuable nutritional content of millet had been reported as having the potential to enhance household food security in Africa [3]. Millet has great economic and health importance. For instance millet is known to be a healthy food choice for the heart because of its status as a good source of magnesium (19\% of the daily value for magnesium). Magnesium has been shown in studies to reduce the severity of asthma and 
to reduce the frequency of migraines. Magnesium has also been shown to lower high blood pressure and reduce the risk of heart attack. Other benefits of millet include:

- Development and Repair of Body Tissue

- Substantially Lower Type 2 Diabetes Risk

- $\quad$ Prevent Gallstones

- $\quad$ Protective against Breast Cancer

- $\quad$ Protective against Childhood Asthma

- Cardiovascular Benefits for Postmenopausal Women

People with celiac disease (the most common disease caused by cereal protein ingestion) can replace certain gluten-containing cereals in their diets with millet. Taking into account its yield, nutritional value and health benefits, food producers have developed many products from millet which include Awaokoshi (candied millet puffs), Millet beer, Rakshi (Distilled liquor), Boza (fermented drink), millet porridge etc. In view of its current uses and health benefits, the study sought to produce millet based sponge cake, determine its nutritional and sensory characteristics.

\section{Methodology}

\subsection{Flour Preparation}

Millet seeds were sorted and washed to remove all unwanted particulates after which seeds were soaked for 24hours. Soaked seeds were milled and flour sun dried for 12hours. Wheat flour produced by Takoradi Flour Mills was purchased from Abura market in Cape Coast.

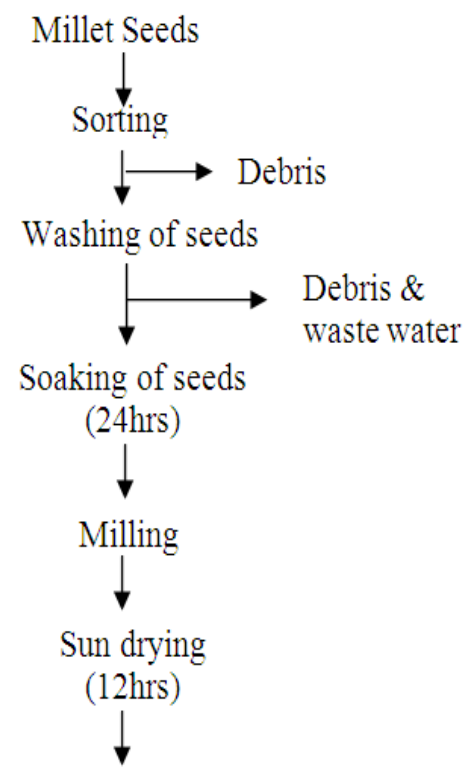

Millet flour

Figure 1. Flow chart for millet flour production

\subsection{Sponge Cake Production}

Cake recipe as described by [4] was used but the ratio of flours used is shown in Table 1.0
Table 1. Ratio of wheat to millet flour used

\begin{tabular}{ccc}
\hline Sample Codes & Wheat flour(g) & Millet flour(g) \\
\hline A & 500 & 0 \\
B & 450 & 50 \\
C & 400 & 100 \\
D & 350 & 150 \\
E & 300 & 200 \\
F & 250 & 250 \\
G & 50 & 450 \\
H & 100 & 400 \\
I & 150 & 350 \\
J & 200 & 300 \\
K & 0 & 500 \\
\hline
\end{tabular}

Source: Lab work (2013)

\subsection{Sensory Analysis}

Forty untrained panel were selected for the sensory analysis after their concerns were sought and their demographic information gathered using Cape Coast Polytechnic Research Consent and Sample Survey Form respectively. Panels were presented with coded samples (Table 1.0) and water to rinse their mouth after tasting each sample. Each panel evaluated eleven (11) samples for visual puffiness, appearance/colour, smell/aroma, taste, overall texture/mouthfeel, moistness, and overall liking on a 9-point hedonic scale ( $1=$ dislike extremely, $5=$ neither like nor dislike, 9=like extremely). Their assessments were then recorded on a Sensory Analysis Forms. Setup for the sensory analysis is as shown below:

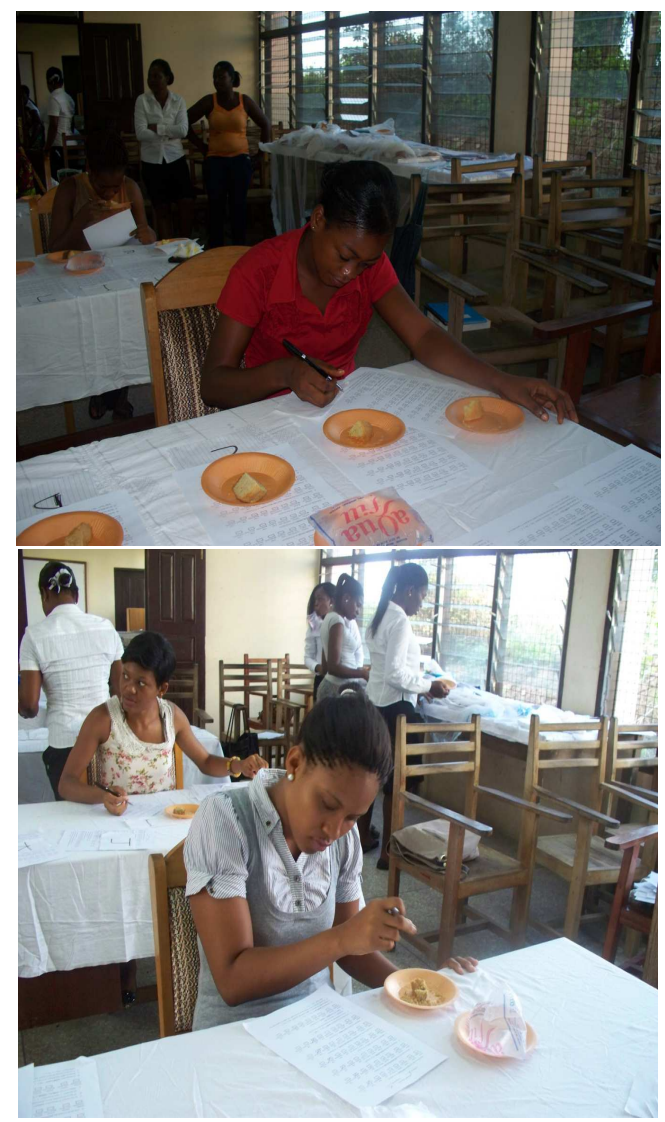

Figure 2. Sensory analysis setup 


\subsection{Nutritional Analysis}

Each sample was tested for percent carbohydrate, fat, ash, protein and moisture content using the Association of Official Agricultural Chemists methods as describe by [5]

\section{Results and Discussion}

\subsection{Results}

\subsubsection{Proximate Analysis of the Millet Cakes}

Table 2. Proximate values of millet based cake

\begin{tabular}{|c|c|c|c|c|c|}
\hline Sample & \% Moisture & $\%$ Ash & $\%$ Protein & $\%$ Fat & $\%$ Carbohydrate \\
\hline A & 12.69 & 1.53 & 7.44 & 30.96 & 77.43 \\
\hline B & 14.48 & 1.89 & 9.47 & 36.30 & 66.00 \\
\hline $\mathrm{C}$ & 18.95 & 2.7 & 8.42 & 33.19 & 65.65 \\
\hline $\mathrm{D}$ & 15.91 & 2.48 & 7.45 & 31.74 & 77.90 \\
\hline $\mathrm{E}$ & 15.41 & 1.91 & 7.20 & 31.74 & 70.78 \\
\hline $\mathrm{F}$ & 16.42 & 1.92 & 6.86 & 31.02 & 69.78 \\
\hline G & 16.74 & 2.12 & 6.42 & 32.33 & 63.63 \\
\hline $\mathrm{H}$ & 14.76 & 2.55 & 7.71 & 33.53 & 76.11 \\
\hline I & 15.92 & 1.99 & 6.82 & 32.6 & 73.86 \\
\hline $\mathrm{J}$ & 16.46 & 1.95 & 7.68 & 31.72 & 77.46 \\
\hline K & 16.67 & 1.79 & 6.21 & 42.36 & 66.87 \\
\hline Standard deviation & 1.58 & 0.36 & 0.92 & 3.32 & 5.38 \\
\hline Mean values & 15.86 & 2.08 & 7.43 & 33.41 & 71.41 \\
\hline
\end{tabular}

The result from the proximate analysis (Table 2.0) shows a general increase in the nutritional values of the samples compared to the control sample (A) with the exception of the carbohydrate content. This might be due to the fact that the carbohydrate content of the millet used was low and that increasing the millet content decreases the approximate carbohydrate value.

Table 3. Nutrient profile comparison of millet with other food staples

\begin{tabular}{|c|c|c|c|c|c|c|c|}
\hline \multirow{2}{*}{ Synopsis composition } & \multicolumn{7}{|c|}{ Component (per 100g portion, raw grain) } \\
\hline & Cassava & Wheat & Rice & Sweet corn & Potato & Sorghum Millet & Proso Millet \\
\hline Water $(\mathrm{G})$ & 60 & 13.1 & 12 & 76 & 82 & 9.2 & 8.7 \\
\hline Energy $(\mathrm{Kj})$ & 667 & 1368 & 1527 & 360 & 288 & 1418 & 1582 \\
\hline Protein $(G)$ & 1.4 & 12.6 & 7 & 3 & 1.7 & 11.3 & 11 \\
\hline Fat (G) & 0.3 & 1.5 & 1 & 1 & 0.1 & 3.3 & 4.2 \\
\hline Carbohydrates $(\mathrm{G})$ & 38 & 71.2 & 79 & 19 & 16 & 75 & 73 \\
\hline Fiber $(G)$ & 1.8 & 12.2 & 1 & 3 & 2.4 & 6.3 & 8.5 \\
\hline Sugars (G) & 1.7 & 0.4 & $>0.1$ & 3 & 1.2 & 1.9 & \\
\hline Iron $(\mathrm{Mg})$ & 0.27 & 3.2 & 0.8 & 0.5 & 0.5 & 4.4 & 3 \\
\hline Manganese (Mg) & 0.4 & 3.9 & 1.1 & 0.2 & 0.1 & $<0.1$ & 1.6 \\
\hline Calcium (Mg) & 16 & 29 & 28 & 2 & 9 & 28 & 8 \\
\hline Magnesium $(\mathrm{Mg})$ & 21 & 126 & 25 & 37 & 21 & $<120$ & 114 \\
\hline Phosphorus (Mg) & 27 & 288 & 115 & 89 & 62 & 287 & 285 \\
\hline Potassium (Mg) & 271 & 363 & 115 & 270 & 407 & 350 & 195 \\
\hline Zinc $(\mathrm{Mg})$ & 0.3 & 2.6 & 1.1 & 0.5 & 0.3 & $<1$ & 1.7 \\
\hline Pantothenic Acid (Mg) & 0.1 & 0.9 & 1.0 & 0.7 & 0.3 & $<0.9$ & 0.8 \\
\hline Vit. B6 (Mg) & 0.1 & 0.3 & 0.2 & 0.1 & 0.2 & $<0.3$ & 0.4 \\
\hline Folate $(\mu \mathrm{g})$ & 27 & 38 & 8 & 42 & 18 & $<25$ & 85 \\
\hline Thiamin (Mg) & 0.1 & 0.38 & 0.1 & 0.2 & 0.1 & 0.2 & 0.4 \\
\hline Riboflavin (Mg) & $<0.1$ & 0.1 & $>0.1$ & 0.1 & $>0.1$ & 0.1 & 0.3 \\
\hline Niacin $(\mathrm{Mg})$ & 0.9 & 5.5 & 1.6 & 1.8 & 1.1 & 2.9 & 4.7 \\
\hline
\end{tabular}

Source: [6] 


\subsubsection{Demographic Information of Panel}

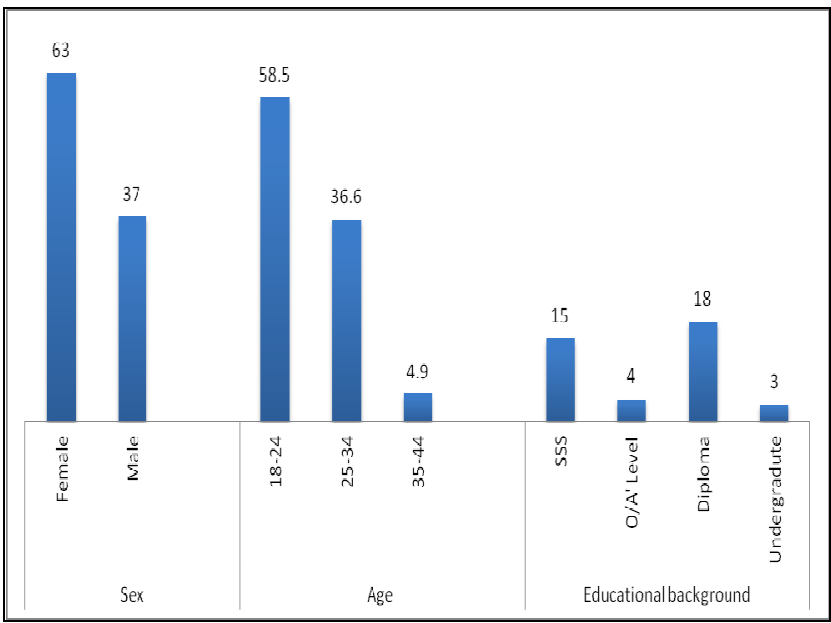

Figure 3. Demographic information of panel

The demographic information of the panel is shown in Figure 3.0. The age distribution shows that $58.5 \%$ of the panel were between the ages of 18-24years, $36.6 \%$ were between the ages of 25-34years whiles $4.9 \%$ were between the ages of 35-44years. The number of female panel used was $63 \%$ while that of male was $37 \%$.

\section{Product information}

Panel were asked on information about cake products and their responses are shown below.

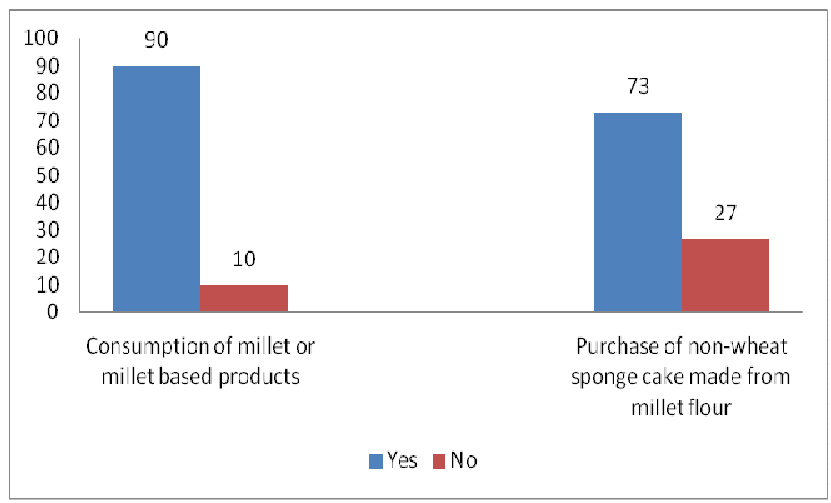

Figure 4. Purchase and consumption of millet or millet based products

Panel were asked if they consume millet and millet based products and their responses as shown in Figure 4.0 revealed that $90 \%$ of the panel consume millet or millet based product whiles $10 \%$ responded that they do not consume such products. The survey revealed that $73 \%$ of the panel would buy non-wheat sponge cake made from millet flour, while $27 \%$ would not. This indicates that majority of the panel would purchase sponge cake made from millet flour.

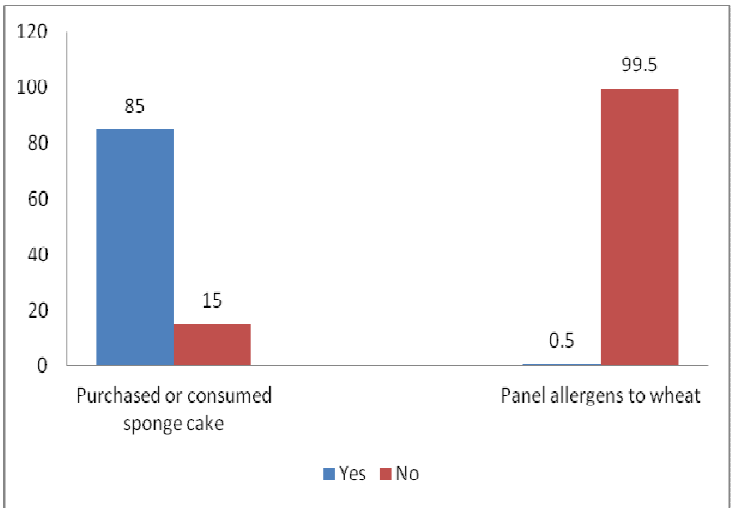

Figure 5. Purchased or consumed of sponge cake and wheat allergen

Figure 5.0 shows that $85 \%$ of the panel purchased and/or consumed sponge cake while $15 \%$ do not. Panel's allergen to wheat from the survey shows that $99.5 \%$ are not allergic to wheat while $0.5 \%$ responded that they were allergic to wheat.

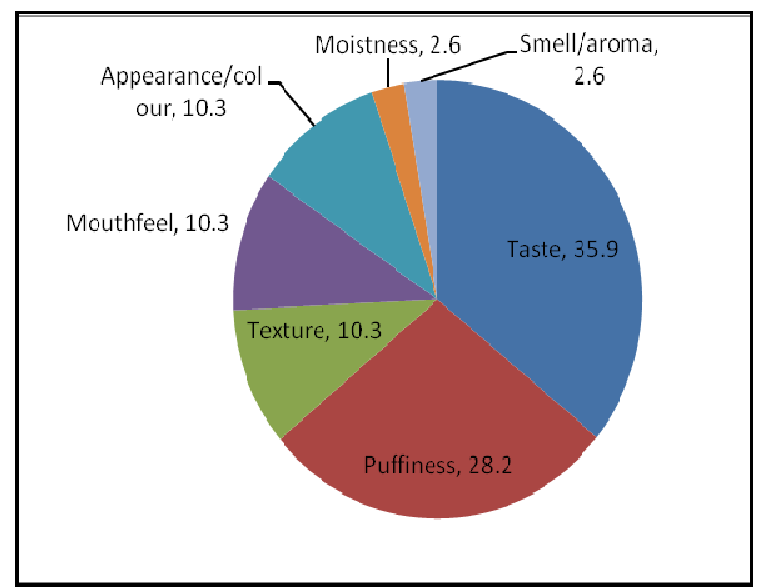

Figure 6. Most important sensory attribute panel want from sponge cake

The sensory attributes panel wants from sponge cake as revealed by the survey is shown in Figure 6.0 among these attributes were taste $(35.9 \%)$, puffiness $(28.2 \%), 10.3 \%$ each for sandiness, mouthfeel and appearance/colour while $2.6 \%$ each likes moistness and aroma of sponge cakes.

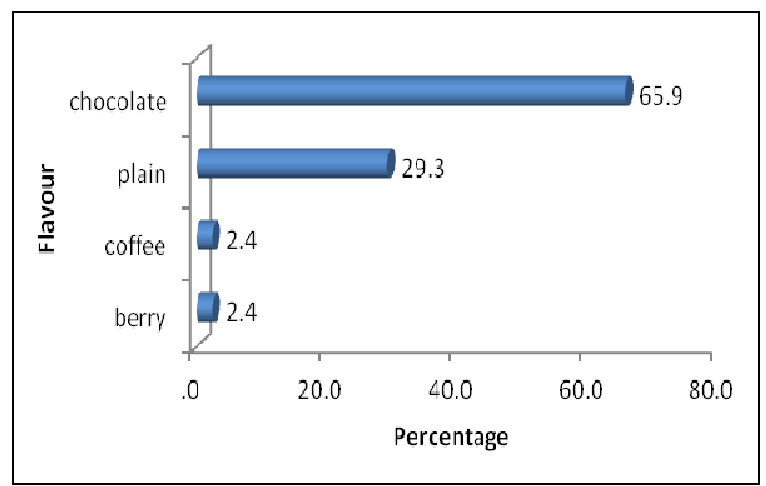

Figure 7. Most favourite flavour for sponge cake 
Panel were asked for their favourite sponge cake flavour. Among the flavours were chocolate $(65.9 \%), 2.4 \%$ each chose coffee and berry while $29.3 \%$ stated that the like plain sponge cake.

\subsubsection{Sensory Assessment of Millet Based Sponge Cake}

Sensory evaluation of the eleven (11) samples for visual puffiness, appearance/colour, smell/aroma, taste, overall texture/mouthfeel, moistness, and overall liking on a 9point hedonic scale $(1=$ dislike extremely, $5=$ neither like nor dislike, 9=like extremely) is shown in Table 4.0 which illustrates the mean assessment values and standard deviations.

Table 4. Sensory assessment of the millet based samples

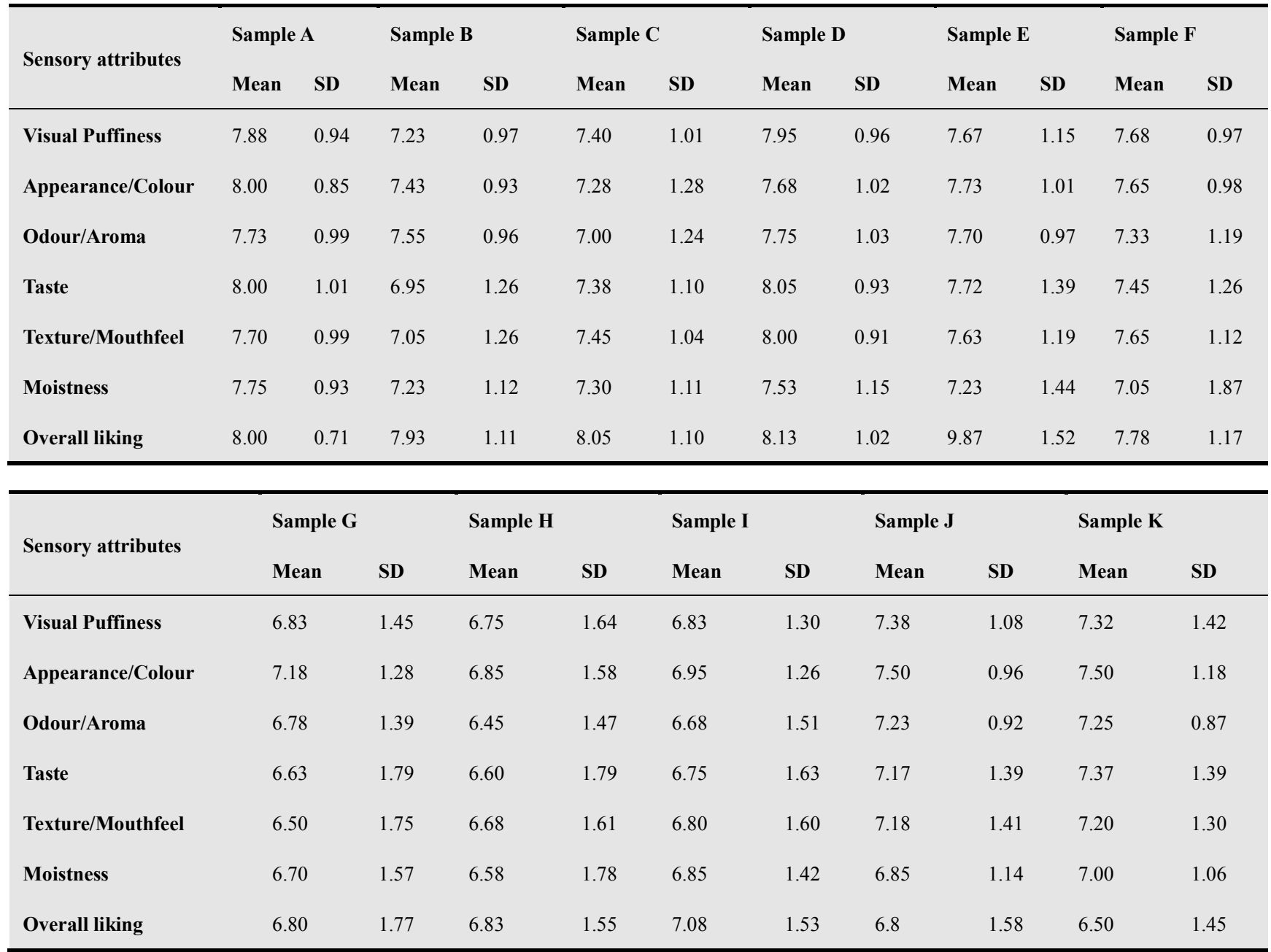

Table 5. Overall assessments of samples

\begin{tabular}{|c|c|c|c|c|c|c|c|c|c|c|c|c|}
\hline \multirow{3}{*}{ Product Assessment } & \multicolumn{2}{|c|}{ Sample A } & \multicolumn{2}{|c|}{ Sample B } & \multicolumn{2}{|c|}{ Sample C } & \multicolumn{2}{|c|}{ Sample D } & \multicolumn{2}{|c|}{ Sample E } & \multicolumn{2}{|c|}{ Sample F } \\
\hline & YES & NO & YES & NO & YES & NO & YES & NO & YES & NO & YES & NO \\
\hline & $\begin{array}{l}\text { Row } \\
\text { N \% }\end{array}$ & $\begin{array}{l}\text { Row } \\
\text { N \% }\end{array}$ & $\begin{array}{l}\text { Row } \\
\text { N\% }\end{array}$ & $\begin{array}{l}\text { Row } \\
\text { N \% }\end{array}$ & $\begin{array}{l}\text { Row } \\
\text { N \% }\end{array}$ & $\begin{array}{l}\text { Row } \\
\text { N \% }\end{array}$ & $\begin{array}{l}\text { Row } \\
\text { N \% }\end{array}$ & $\begin{array}{l}\text { Row } \\
\text { N \% }\end{array}$ & $\begin{array}{l}\text { Row } \\
\text { N \% }\end{array}$ & $\begin{array}{l}\text { Row } \\
\text { N \% }\end{array}$ & $\begin{array}{l}\text { Row } \\
\text { N \% }\end{array}$ & $\begin{array}{l}\text { Row } \\
\text { N \% }\end{array}$ \\
\hline Sandy & 62.5 & 37.5 & 75.00 & 25.00 & 67.5 & 32.5 & 72.5 & 27.5 & 70.0 & 30.0 & 65.0 & 35.0 \\
\hline $\begin{array}{l}\text { Is this Product } \\
\text { Acceptable }\end{array}$ & 100.0 & 0.0 & 95.00 & 5.00 & 97.5 & 2.5 & 97.5 & 2.5 & 97.5 & 2.5 & 97.5 & 2.5 \\
\hline $\begin{array}{l}\text { Would you buy product } \\
\text { if it were commercially } \\
\text { available }\end{array}$ & 100.0 & 0.0 & 82.50 & 17.50 & 97.5 & 2.5 & 90.0 & 10.0 & 92.5 & 7.5 & 92.5 & 7.5 \\
\hline $\begin{array}{l}\text { If Allergic to Wheat, will } \\
\text { you buy this product }\end{array}$ & 97.5 & 2.5 & 77.50 & 22.50 & 95.0 & 5.0 & 95.0 & 5.0 & 97.4 & 2.6 & 95.0 & 5.0 \\
\hline
\end{tabular}




\begin{tabular}{|c|c|c|c|c|c|c|c|c|c|c|}
\hline \multirow{4}{*}{ Product Assessment } & \multicolumn{2}{|c|}{ Sample G } & \multicolumn{2}{|c|}{ Sample H } & \multicolumn{2}{|c|}{ Sample I } & \multicolumn{2}{|c|}{ Sample J } & \multicolumn{2}{|c|}{ Sample K } \\
\hline & YES & NO & YES & NO & YES & NO & YES & NO & YES & NO \\
\hline & Row & Row & Row & Row & Row & Row & Row & Row & Row & Row \\
\hline & $\mathrm{N} \%$ & $\mathrm{~N} \%$ & $\mathrm{~N} \%$ & $\mathrm{~N} \%$ & $\mathrm{~N} \%$ & $\mathrm{~N} \%$ & $\mathrm{~N} \%$ & $\mathrm{~N} \%$ & $\mathrm{~N} \%$ & $\mathrm{~N} \%$ \\
\hline Sandy & 72.5 & 27.5 & 75.0 & 25.0 & 82.5 & 17.5 & 77.5 & 22.5 & 70.0 & 30.0 \\
\hline Is this Product & & & & & & & & & & \\
\hline $\begin{array}{l}\text { Acceptable } \\
\text { Would you buy this } \\
\text { product if it was }\end{array}$ & 77.5 & 22.5 & 72.5 & 27.5 & 80.0 & 20.0 & 92.5 & 7.5 & 87.5 & 12.5 \\
\hline $\begin{array}{l}\text { commercially available } \\
\text { If Allergic to Wheat, }\end{array}$ & 72.5 & 27.5 & 72.5 & 27.5 & 72.5 & 27.5 & 82.5 & 17.5 & 85.0 & 15.0 \\
\hline would buy the product & 65.0 & 35.0 & 65.0 & 35.0 & 67.5 & 32.5 & 75.0 & 25.0 & 85.0 & 15.0 \\
\hline
\end{tabular}

Sensory assessments of the products on the 9 point hedonic scale (Table 4) show that all products scores were more than 6 on the scale which is an indication that all sensory attributes were at least liked slightly in each case by the panel.

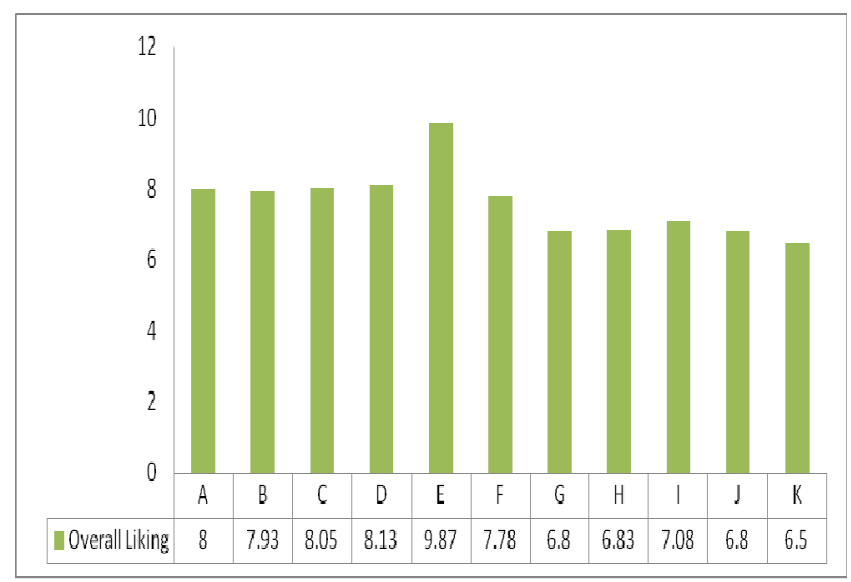

Figure 8. Overall liking of products

Panel assessment on the overall likeness of the products (Figure 8.0) shows that as the ratio of millet flour to that of wheat flour increases (Sample A to E), panel liking also increased. However, when ratios of millet to wheat were 1:1 and above (Sample $\mathrm{F}$ to $\mathrm{K}$ ) their likeness decreased. The assessment showed that Sample E was the most preferred.

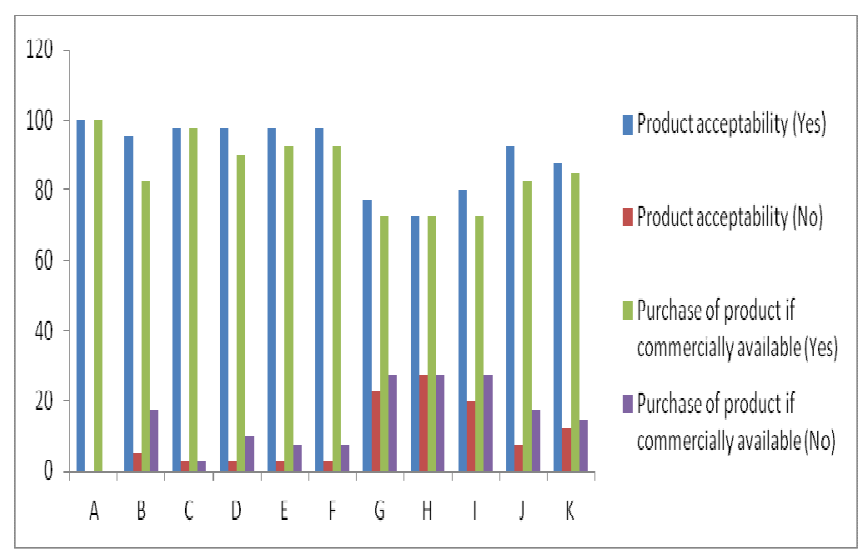

Figure 9. Acceptability and purchase of product on commercial bases
Product assessment, acceptability and whether panel would buy product if commercially available as shown in Table 5.0 and Figure 9.0 revealed that almost all the products were acceptable to most of the panels and that would buy products if commercially available. However with the exception of sample A, few of the panel stated that products were not acceptable and that would not purchase products if they were commercially available.

\subsection{Discussion}

Food companies are faced with an increased demand by health professionals and consumers for healthier food products. According to [7], the need for flours that are free of gluten (such as millet, tapioca, potato, soy, flax, etc.) is becoming progressively more popular in the mainstream supermarket, therefore offering new sales potential for food companies. It is against this background that the study was performed to produce millet based cake with the view of improving the sensory and nutritional values of the products.

The nutritional analysis (Table 2.0) shows that, as the ratio of wheat to millet decreased, the overall nutritional value of the product increased. Millet has higher fat and carbohydrate content (Table 3.0) than wheat hence increasing the millet content does increased the fat and carbohydrate values of the cake samples. Although wheat has high moisture content than millet, it was expected that reducing the wheat flour content should correspond with reduced moisture content, the analysis shows otherwise. This trend might be due to the fact that the drying process of the millet flour was not effective.

Significant differences in visual puffiness, appearance, texture/mouthfeel, moistness and smell acceptability were not observed among the products (Table 4). Superimposition of the optimal areas having a score greater than 6.0 from each attribute was done to obtain an optimal formulation range. However, the sensory assessments of the products on the 9-point hedonic scale as shown in Table 4.0 depicts that in all, products scores were more than 6 on the scale which is an indication that all sensory attributes were at least liked slightly in each case by the panel.

Although [8] stated that when gluten is removed from bakery products, it negates the desired qualities but this was not so with the millet based cake which shows improved nutritional (Table 2.0) and sensory qualities as the amount 
of millet in the wheat to millets flour ratio increased. Hence the notion that, most gluten-free products currently available on the market are of inferior quality to those containing gluten $[9,10]$ may not be so. Panel assessment on the overall likeness of the products (Figure 8.0) shows that as the ratio of millet flour to that of wheat flour increases (Sample A to E), panel liking also increased. However, when ratios of millet to wheat were 1:1 and above (Sample F to K) their likeness decreased. Their overall likeness as shown in Figure 8.0 show that consumers liked Sample E (Wheat (300g): Millet (200g)). Logistic regression analyses identified overall liking, taste and texture as attributes critical to overall acceptance and purchase decision. These attributes served as the limiting factors to obtain the optimal formation range. The product assessment, acceptability and whether panel would buy product if commercially available as shown in Table 5.0 and Figure 9.0 indicated that all products were acceptable to most of the panels and that would buy products if commercially available, however with the exception of sample A, few of the panel stated that products were not acceptable and that would not purchase products if products were commercially available.

\section{Conclusion}

There was improvement on the nutritional contents of the formulation as the proximate analysis general showed an increase in value from the control Sample (A). Panel were able to correctly discriminate between the different samples in terms of the sensory attributes on the 9-point hedonic scale. However, the overall liking of the samples as perceived by the panel indicated that all products were acceptable with Sample E being the most preferred. Positive purchase intent was noticed among the panel hence offering new sales potential for the millet based cakes.

\section{References}

[1] Tuorila, H. and Cardello, A. V. (2002) Consumer responses to an off-flavor in juice in the presence of specific health claims. Food Quality and Preference, 13:561-569.

[2] Dicko, H., Gruppen, H., Traore, A., Voragen, J. And Berker, J. (2005) Sorghum grain as human food in Africa. Relevance of content of starch and amylase activities. African Journal of Biotechnology, 5 (5): 384-395.

[3] Mukarumbwa, P. (2009) Potential of sorghum and finger millet to enhance household food security in Zimbabwe's semi-arid regions: A case study of communal areas in Masvingo Province. Master of Science Dissertation, University of Fort Hare

[4] Campbell, J., Koskett, D and Paskins, P. (2012) Practical cookery for NVQ and apprenticeship. London, UK. Hodder Education.

[5] Nielsen, S. S. (2010) Food analysis. Fourth edition. New York, USA. Springer Science+Business Media

[6] Millet Network of India. URL:http://www.milletindia.org [10/06/2013]

[7] Turcsik, R. 2004. Flour power. Supermarket Grocery Business

[8] Gallagher, E., Gormley, T. R. and Arendt, E. K. (2004) Recent advances in the formulation of gluten-free cerealbased products. Trends in Food Science \& Technology. $15: 143-152$.

[9] Arendt, E. K., O’Brien, C. M., Schober, T. J., Gallagher, E. and Gormley, T. R. (2002) Development of Gluten-Free Cereal Products. Farm \& Food. Summer: 21-27.

[10] Gallagher, E., Polenghi, O., and Gormley, T. R. (2002) Improving the quality of gluten-free breads. Farm and Food. 12: $8-13$. 